\title{
Insiders, outsiders and host country bargains
}

\author{
Lorraine Eden ${ }^{\mathrm{a}, *}$, Maureen Appel Molot ${ }^{\mathrm{b}, 1}$ \\ ${ }^{a}$ Department of Management, Mays Business School, Texas A\&M University, \\ 4221 TAMU, College Station, TX 77843-4221, USA \\ ${ }^{\mathrm{b}}$ The Norman Paterson School of International Affairs, Carleton University, Ottawa, Ontario, Canada K1S 5B6
}

\begin{abstract}
The obsolescing bargain (OB) model analyzes bargaining between a host country (HC) government and a multinational enterprise (MNE) at time of entry and the circumstances under which the original bargain does or does not erode over time. The model has traditionally focused on the dyadic relationship between the MNE and nation state. However, if a second wave of foreign multinationals should enter the HC, the relationship is no longer dyadic but trilateral: the host government, the first mover firms and the latecomers. What happens to the original and to subsequent MNE-state bargains? We incorporate recent insights on the liability of foreignness, transaction cost economics, multimarket competition and the resource-based view (RBV) into a theoretical model of sequential entry by rival multinationals. We find that liability of foreignness, firm rivalry and governance inseparability are key factors determining winners and losers in the sequential bargains. International institutions and home country governments are external forces that can also affect bargaining outcomes. We test our model's propositions on a longitudinal case study of public policy decisions in the Canadian auto industry. (C) 2002 Elsevier Science Inc. All rights reserved.
\end{abstract}

Keywords: Obsolescing bargain; MNE-state relations; Liability of foreignness; Transaction cost economics; Resource-based view; Competitive rivalry; Auto industry; Case study

\section{Introduction}

The obsolescing bargain (OB) model has been the basic building block for analyzing relations between a host country (HC) government and a multinational enterprise (MNE) ever

\footnotetext{
${ }^{*}$ Corresponding author. Tel.: +1-979-862-4053; fax: +1-979-845-9641.

E-mail addresses: leden@tamu.edu (L. Eden), maureen_molot@carleton.ca (M.A. Molot).

${ }^{1}$ Tel.: +1-613-520-2600x6658; fax: +1-613-520-2889.
} 
since the publication of Sovereignty at Bay (1971). The OB model predicts that MNE-HC bargains should initially favor the firm at the time of entry, but the bargains are likely to obsolesce as the state's perceptions of benefits and costs change over time. ${ }^{2}$

What happens in this model if we increase the number of entrants, allow for differing entry dates and examine post-entry bargains? For example, assume a first wave of MNEs enters a $\mathrm{HC}$ and the country then faces a second wave of foreign firms in the same industry. If the original MNEs have become fully integrated into the host economy and no longer suffer from the liability of foreignness that plagues foreign entrants (Hymer, 1960/1976), subsequent entries by rival MNEs should disturb this equilibrium. New entrants should necessitate new bargains that affect the status quo of the first movers. Post-entry bargains now involve three actors: the host government, first mover firms and latecomers.

Our model is applied to a longitudinal case study of public policy making in the Canadian auto industry. Shaffer (1995), in his review of theoretical and research approaches to corporate political behavior, argues that the longitudinal case study design can be a powerful qualitative tool for understanding the links between firm-level strategies, political activity and policy outcomes. We argue that the auto industry in Canada is a good longitudinal case study because the industry has long been dominated by foreign multinationals. The major US assemblers (the Big Three: Ford, General Motors and Chrysler) invested early in the 20th century, acquired all the domestic firms and have dominated the industry since the 1920s. The first wave MNEs (the Big Three) lost their liability of foreignness and became insiders early in this century. Their organizational status as insiders was formalized in the Auto Pact. In the mid-1980s, rival Asian assemblers (Honda, Toyota and Hyundai) moved onshore, setting up new assembly plants and threatening the insider status of the Big Three. Subsequent public policy decisions were negotiated through complex iterated bargains between the Canadian government and the first and second wave entrants. These sequential bargains provide useful cases against which to test the propositions of our model. ${ }^{3}$

The paper is organized as follows. We briefly review the OB literature and then develop our trilateral (insiders, outsiders and HC) bargaining model with five propositions about policy outcomes. The propositions are tested against nine public policy outcomes in the Canadian auto industry. Some of the policy outcomes are 'new' bargains, others the modification of an existing bargain. In Section 5, we show how generalizing the model by changing the core assumptions would alter the outcomes. The paper concludes with suggestions for future research.

\footnotetext{
${ }^{2}$ See, for example, Vernon (1971, 1977), Moran (1973), Bennett and Sharpe (1979), Jenkins (1986), Kobrin (1987), Brewer (1992), Grosse and Behrman (1992), Vachani (1995) and Grosse (1996).

${ }^{3}$ Without specifying a length of time required to attain insider status, iterative bargaining assumes some gap between the initial and later rounds of investment. The Auto Pact was signed in 1965 and the second wave of MNEs entered Canada in the mid-1980s. The period of trilateral bargaining therefore takes place over approximately 15 years.
} 


\section{Literature review}

The OB model explains the changing nature of bargaining relations between an MNE and a $\mathrm{HC}$ as a function of goals, resources and constraints. The model assumes that bargaining is a positive sum game such that both parties voluntarily bargain and achieve absolute gains. Relative gains, however, depend on relative bargaining power. The outcome should favor the party with the stronger resources, higher issue salience, weaker constraints and greater coercive power (Vernon, 1971, 1977; Kobrin, 1987; Brewer, 1992; Grosse and Behrman, 1992; Grosse, 1996; Vachani, 1995).

Relative bargaining power is assumed to initially favor the MNE. Because the MNE has a range of alternatives, the $\mathrm{HC}$ offers locational incentives to attract inward foreign direct investment (FDI). The bargain is, however, expected to obsolesce over time. Once the MNE has made sector-specific investments in the $\mathrm{HC}$, these resources can be held hostage by an opportunistic $\mathrm{HC}$ government. The longer the MNE is in the $\mathrm{HC}$, the more likely it is that the government's perception of the benefit-cost ratio offered by the MNE falls, particularly if the investment turns out to be highly profitable and there are large remittances to the foreign parent. At the same time, technological spillovers and economic development encourage the emergence of local competitors, so the HC becomes less dependent on the MNE over time. This suggests that the $\mathrm{HC}$ is likely to demand more from the $\mathrm{MNE}$, causing the original bargain to obsolesce.

While Vernon's (1971) OB model assumed the HC was a developing country and the MNE entered to extract its natural resources, the model was subsequently extended to manufacturing and to OECD countries (Moran, 1985). In manufacturing, MNE-HC bargains are less likely to obsolesce because the investments tend to be smaller and more mobile, and the knowledge-based advantages of the MNE more difficult to copy. If the MNE can supply the $\mathrm{HC}$ with a stream of new investments, the bargain need not decay. The MNE can also delay obsolescence through its own activities, by forming strategic alliances with local firms, diversifying activities outside the $\mathrm{HC}$, establishing multiple sites to reduce the probability of being held hostage and offering more benefits to the host government (Grosse and Behrman, 1992).

Using percent of ownership as a measure of bargaining success, Kobrin (1987) found evidence that suggested the MNE-HC bargain did not obsolesce for manufacturing MNEs, particularly in high technology sectors. Bennett and Sharpe (1979) found that Mexico's bargaining power was strongest at time of entry because the automotive MNEs desired access to the HC market. Once the MNEs had become integrated into the host economy and developed strong relationships with local upstream and downstream firms, MNE bargaining power increased rather than obsolesced. Technology transfer also kept Mexico dependent on the foreign auto MNEs.

On the other hand, Vachani (1995) found some support for the OB model in a study of nationalizations by the Indian government of US, British and European subsidiaries between 1973 and 1985. Vachani argued for differentiating static bargaining success (the outcome of a particular negotiation) from dynamic bargaining success (the long-run trend in outcomes over several negotiations) because factors important for one might not be important for the other. 
Over the longer term, the MNE's technology intensity and size of investment were positively related to its ability to prevent the bargain from obsolescing.

Even in vertically integrated, natural resource-intensive industries, there is evidence that MNEs have been able to protect their bargains. Moran (1973) found that Kennecott developed domestic and transnational alliances which, when the firm was nationalized by the Chilean government in 1971, were successful in getting Kennecott nearly full compensation for its investments. Anaconda, which had not developed any alliances, was nationalized without any compensation. Jenkins (1986) found that even in the petroleum industry, the oil MNEs were able to defeat the National Energy Program in Canada by enlisting the US government on their behalf, shifting their oil rigs outside of Canada and cancelling new investments.

In summary, the widely held view among international business scholars is that the OB model has outlived its usefulness. The many case studies testing the model suggest that MNEs were able to retain relative bargaining power and prevent opportunistic behavior by HC governments so the bargains, in practice, seldom obsolesced. Today, few governments restrict inward FDI, either in the form of screening or performance requirements, so that little formal bargaining occurs between MNEs and host governments. Most MNE-government relations are seen as cooperative, not conflictual (Dunning, 1993a; Luo, 2001). As a result, there appear to be few areas where the OB model appears to apply.

We argue that the OB model can be revitalized if, first, we broaden the issue area by recognizing that firms and governments engage in iterative bargaining over a wide variety of government policies at the industry level. First movers want not only to maintain the original bargain but also search for new bargains that will enhance their competitive position. Obtaining favorable outcomes in these public policy debates is critically important to firm competitiveness and performance. Second, even if MNE-state relations are cooperative, democratic governments must also take into account the interests of stakeholders (e.g., consumers and labor groups) and commitments (e.g., membership in international organizations) so that, in practice, MNEs must bargain for favorable public policies. Lastly, the OB model still has utility for understanding bargaining processes and outcomes, even if the bargains do not obsolesce.

\section{Theory development}

\subsection{Relative goals}

We start by assuming, as does the traditional MNE-HC bargaining model, that both parties have goals they want to accomplish and attach a level of importance or salience to the particular negotiation. Grosse and Behrman (1992) argue that it is the (dis)similarity of interests between the two parties that is relevant for the negotiations. The more similar the goals, the less difficult the bargaining process and the less the need for the host government to regulate and/or coerce the MNE into activities seen as beneficial by the HC. 
The MNE's goals can be conceptualized at two levels. First, the MNE has specific motives for entry (Dunning, 1993b). Underlying these specific motives is a more diffuse set of objectives - efficiency, market power and legitimacy - designed to help the MNE maximize its long-run after-tax global returns (Boddewyn and Brewer, 1994). While the efficiency and market power objectives of the MNE are well understood, less is known about the MNE's legitimacy seeking objective.

Hymer (1960/1976, p. 35) was the first international business scholar to argue that firms face a "stigma of foreignness" when they attempt to enter and operate in foreign countries. The liability of foreignness comes from being a "stranger in a strange land" (Heilein, 1961) and having to face costs not borne by local firms. The foreign firm is both in a "strange land" and simultaneously a "stranger" to stakeholders in the HC. Foreign firms are outsiders; domestic firms insiders.

MNE entrants therefore want organizational legitimacy, that is, the right to operate in a foreign market as a domestic firm (Keillor et al., 1997; Kostova and Zaheer, 1999). Organizational legitimacy includes but is broader than the national treatment norm familiar from international law; legitimacy encompasses all the rights, privileges and responsibilities available to national firms. In effect, legitimacy confers insider status on foreign firms since an MNE with organizational legitimacy is perceived and treated by the $\mathrm{HC}$ as if it were a domestic firm. We therefore equate legitimacy to being an insider in the HC (Eden and Molot, 1993a).

Because the foreign firm is not automatically entitled to the same rights and privileges as domestic firms, nor can the MNE's home government offer the same protections abroad as at home, the MNE is dependent on the HC for legitimacy. Since the host government lacks information about the foreign firm and is therefore likely to have stereotypical views and/or discriminate, the host government treats the MNE as a stranger and outsider without legitimate status in the HC. A critical goal for an entering MNE is thus to overcome the liability of foreignness and achieve organizational legitimacy inside the $\mathrm{HC}$ as soon as possible.

Legitimacy can be achieved if the MNE becomes isomorphic with the institutional environment in the $\mathrm{HC}$; however, it takes time and commitment by the MNE to build a reputation and become recognized as an insider (Zaheer, 1995; Zaheer and Mosakowski, 1997). Legitimacy is also more likely to be enhanced when the MNE develops partnerships with local institutions (Boddewyn and Brewer, 1994), has personal relations with host government officials and firms, and is seen by them as having high organizational credibility (Luo, 2001). Where the HC is significantly different from the MNE's home country or other locations, the need for national responsiveness in order to ensure external legitimacy in the $\mathrm{HC}$ may come at the expense of impairing global efficiencies for the multinationals (Rugman and Verbeke, 1998).

The host government hopes to accomplish economic, social and political objectives through negotiations with the foreign firm(s). Traditionally, MNE-HC goals have been seen as conflictual (Vernon, 1971; Moran, 1985). More recently, with market liberalization and globalization, HC goals have shifted toward achievement of international competitiveness through strong home bases. "The unique and critical role of modern democratic 
governments is to create and sustain an efficient economic system," which means that "governments and firms are best considered as partners in the wealth-creating process" (Dunning, 1997, pp. 118, 128). Because MNEs are now seen as key actors in the process of transferring and facilitating international competitiveness, MNE-HC relations are now viewed as cooperative rather than competitive, reflecting the shared goals of efficiency gains and international competitiveness (Dunning, 1993a; Luo, 2001). With both parties seeing benefits from combining the MNE's core advantages with the HC's location-bound assets, MNE-state goals are less likely to be conflictual and negotiations should be more harmonious. This suggests that the power of ideas to change MNE-HC bargaining outcomes may be very strong.

The size of the stakes can also affect MNE-HC bargaining and the outcome. While each party has general goals it hopes to accomplish, the importance each party attaches to the negotiations may differ. The stakes depend on the availability of alternatives to each party (the next best available alternative should deadlock occur), the importance of this particular negotiation to each party in the context of the overall MNE-HC relationship, and the importance of this negotiation in the context of each party's overall interests.

\subsection{Relative resources}

Both parties are assumed to possess assets or resources that are valuable to the other. The MNE's resources are its firm-specific assets (FSAs) that are difficult to imitate (Teece et al., 1997). Based on insights from the resource-based view (RBV) of the firm, we argue that competitive advantage is derived from the firm's FSAs if they are rare, hard to imitate, have no direct substitutes, and enable companies to pursue opportunities or avoid threats (Barney, 1991). The firm's ability to earn sustainable above-normal rents (either Ricardian or monopoly rents) is dependent on its possession of heterogeneous resources, skills and capabilities, ex ante and ex post limits to industry competition, and imperfect factor mobility (Peteraf, 1993, p. 185). We assume the MNE possesses three types of resources, based on the method by which they are protected from imitation: resources protected by property rights, tacit resources and relational resources.

Property-based resources are "enforceable long-run contracts that monopolize scarce factors of production, embody exclusive rights to a valuable technology, or tie up channels of distribution... they buffer an organization from competition by creating and protecting assets that are not available to rivals - at least not under equally favorable terms" (Miller and Shamsie, 1996, p. 522). Exclusive ownership of a valuable resource that cannot be legally imitated by rivals means that its owner can earn superior rents on the resource. Any rival firm that wants the resource must pay the discounted future value of the expected economic returns from the resource. Property-based resources may be discrete (ownership of a scarce and valuable input, facility, location or patent) or systemic (ownership of an integrated supply, manufacturing and distribution system) in nature. The benefits of property-based resources are specific and fixed because they are developed and have value for a particular environment or set of circumstances. This means that when circumstances change the value of propertybased resources may disappear. 
Where FSAs are not protected by contracts, there are at least two other categories that may satisfy Barney's resource definition. First, internal tacit resources, by definition, are subtle and hard to understand, based on routines and learning by doing. Because they are hard to transfer, their value is protected not by property rights but by knowledge barriers. These resources may be discrete (specific technical, functional or creative skills) or systemic (teambuilding and collaborative skills). Because they are less specific and more flexible, tacit resources should be more valuable than property-based resources in changing and unpredictable environments (Miller and Shamsie, 1996). Second, external relationships that facilitate knowledge sharing, privileged access to resources or customers and/or erect barriers to entry may confer monopoly rents. These relation-based resources can arise through strategic alliances between firms or business-government relationships. Strategic alliances should be seen as the external counterpart to the internal tacit resources that arise from multidisciplinary teamwork within the firm.

In sum, the MNE's resources/FSAs are its bundle of tangible and intangible assets that give rise to long-lived rents, where the MNE either owns property rights in the asset (or complementary assets) or its value is protected from erosion due to the tacit or relationalbased nature of the asset. Let us call the former property-based resources and the latter, tacit/ relation-based resources.

The HC's resources, in the OB model, are seen as its country-specific advantages (CSAs): access to the local market, abundant raw materials, cheap labor, etc. With globalization, the increasing mobility of capital and the decreasing importance of unskilled labor and raw materials, the HC's resources need to also be redefined, in the same way that FSAs have been redefined by the resource-based view of the firm. We therefore hypothesize that the HC's true locational advantages are its location-bound assets that are rare, hard to imitate, have no direct substitutes, and enable firms using those resources to pursue opportunities or avoid threats. Governments can positively affect the value of their 'home bases' through dynamic efficiency-enhancing investments and a regulatory environment that encourages technological upgrading, reduction of transaction costs and openness to the global economy (Dunning, 1997).

In any bargaining situation, the value of each party's resources is measured, not by its owner's evaluation, but by the other party's desire for those resources. The other party's valuation depends on the strength of desire/need for the particular resource and on what other alternatives are available should the negotiation fail. Transaction cost economics implies that bargaining power comes from the ability to withhold resources that the other party wants. HC bargaining power is stronger when it has rare, location-bound CSAs that are desired by the MNE. MNE bargaining power is stronger when the HC wants FSAs that are inimitable and in scarce supply. Thus, it is the relative resources of the MNE vis à vis the HC that are the underlying determinant of potential bargaining power in each negotiation.

Luo (2001) argues that resource complementarity is also an important factor influencing outcomes. The greater the perceived complementarity between the MNE's and HC's resources, the higher each will value the other's resources. In the absence of other alternatives, the greater will be their bilateral interdependence, the higher the salience each party will attach to the bargaining process and the more attention each party will devote to 
MNE-state relations. In these circumstances, Luo expects more cooperative relations, higher benefits for the MNE and stronger firm performance in the $\mathrm{HC}$.

\subsection{Relative constraints}

The exercise of potential bargaining power based on each party's resources, as valued by the other party, may be constrained. Constraints on HC bargaining power can be political (e.g., a weak, politically unstable government that lacks legitimacy), institutional (e.g., HC actions are constrained by international agreements) or economic (HC balance of payments difficulties). Constraints on the MNE's bargaining power can also be political (previous commitments to the host or home country), institutional (membership in international organizations) or economic (restrictions imposed on the subsidiary by its parent firm). Because MNE legitimacy in the HC depends on the host government, direct governmental coercion (e.g., nationalization and taxation) is also a possibility constraining the MNE's options. These constraints may also be either internal (within the MNE and HC) or external (imposed by third parties or external institutions).

Transaction cost economics suggests that previous contracting arrangements can constrain current negotiations. Argyres and Liebeskind (1999) argue that previous contracts can cause governance inseparability, that is, an agent's past governance choices can restrict the range and type of governance mechanisms the agent can adopt in the future. This is because contracts are difficult to reverse; "a firm's contractual commitments tie it to specific other parties who have rights in relation to the firm" (Argyres and Liebeskind, 1999, p. 52). Governance inseparability creates two problems for the agent: the inability to engage in governance switching (changing modes) or governance differentiation (adding new modes). Thus, in repeated negotiations with the same $\mathrm{MNE}(\mathrm{s})$, involving modifications of the initial contract or the addition of new deals, the host government may be constrained by earlier bargains with the same firm(s). When new firms enter, their MNE-HC bargains are likely to be constrained by the existence of the earlier HC bargains with the first mover firms. Similarly, an MNE's options may be limited by its prior agreements with the HC, other governments or other firms.

An important constraint that is given little recognition in the original OB model is the role now played by international institutions (see, however, Ramamurti, 2001). Because most developed and developing governments are members of multilateral organizations (e.g., World Trade Organization, (WTO)), multilateral rules negotiated between national governments now constrain MNE-HC bargaining. Bilateral investment treaties (BITs) are now widespread. Regional trade agreements such as the North American Free Trade Agreement (NAFTA) and the European Union regulate FDI flows within trading blocs. At the multilateral level, the failed Multilateral Agreement on Investment would have extended the BIT framework to all OECD member countries. The web of agreements is creating an investment regime (Eden, 1996) that offers more protection, and bargaining leverage, to multinationals.

The existence of economic, political and institutional constraints suggests that actual bargaining power will differ from potential power. Actual bargaining power may be greater or 


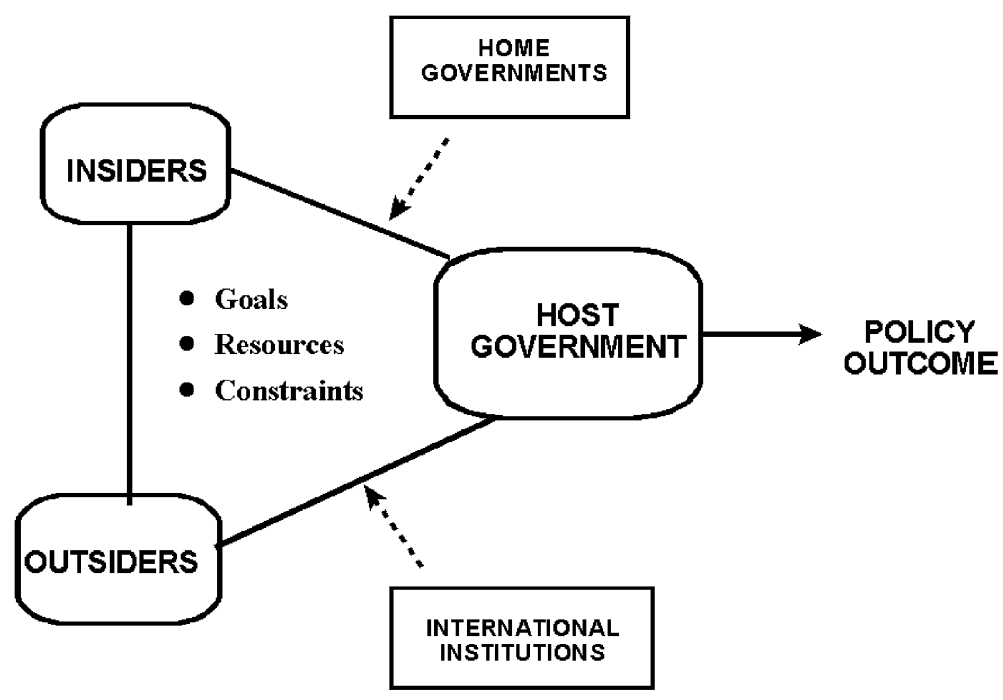

Fig. 1. Insiders, outsiders and host country bargains.

less than potential power, depending on several factors: the resources controlled by one party and demanded by the other, the similarity of interests and relative stakes attached to the negotiation, the constraints on each party, and the ability of either party to limit the behavior of the other party directly through economic or political coercion.

\subsection{Bargaining outcomes}

In the original $\mathrm{OB}$ model, the $\mathrm{HC}-\mathrm{MNE}$ bargaining is over the initial firm-specific entry decision (e.g., FDI screening) and subsequent monitoring of the MNE by the host government. However, we argue that the $\mathrm{HC}-\mathrm{MNE}$ bargaining model should be conceptualized as much broader in scope. MNEs and governments bargain over a wide variety of government policies at the industry level; in some cases, individual firms will have very different policy positions; in others, they may lobby as a group. Over time, through iterative bargaining, MNEs actively attempt to shape government policies toward their industry, and, as a result, their own efficiency, market power and legitimacy goals. Bargaining outcomes in these public policy debates should depend on the relative goals, resources and constraints of the two parties, as outlined above, with the "winner" being the party whose goals are most closely mapped by the outcome. Fig. 1 illustrates our MNE-HC bargaining model, which we discuss below. 4

\footnotetext{
${ }^{4}$ We acknowledge the suggestion of an anonymous reviewer that there is a difference between negotiating an initial contract and modifying it. In our analysis, we do not distinguish analytically between the initial and subsequent bargains. However, some of our cases (FTA, NAFTA and WTO) address the modification of an existing bargain (the Auto Pact), whereas others (VERs, Honda) are new bargains. The effort mounted by industry actors was not shaped by the newness of the bargain, but rather by stakeholders' perceptions of the salience of the issue.
} 


\subsubsection{First wave bargains}

The first wave of MNEs is assumed to enter the HC, seeking legitimacy and economic returns (from efficiency and/or oligopolistic power). They must overcome the liability of foreignness costs by offering access to their nonlocation-bound resources that are propertybased, tacit and/or relational. In order to attract inward FDI, the HC offers access to its local resources. Making the traditional assumptions of the OB model (resource complementarity, fewer alternatives for the $\mathrm{HC}$ than the MNE) we predict that:

Proposition 1: The initial MNE-HC bargains of the early entrants should favor the MNE entrants, ceteris paribus.

The MNEs receiving this privileged access have discrete property-based resources that enable them to erect barriers to entry to other firms, both multinational and domestic. Politically astute MNEs invest in relation-based assets, building personal networks with local firms and state and local governments in the $\mathrm{HC}$, following nationally responsive strategies that help reduce the liability of foreignness. Political responsiveness to $\mathrm{HC}$ needs and goals increases affiliate "face value" in the eyes of $\mathrm{HC}$ stakeholders and strengthens MNE-HC relations (Luo, 2001).

As the first entrants acquire legitimacy (a key relational resource) and are treated as insiders in the HC, they extend and consolidate their property-based assets (e.g., superior geographic locations and distribution networks). The MNEs become a strategic group of local enterprises with stable market positions, protected by industry and/or government-imposed barriers to entry. Thus, early entry can enhance the accumulation of superior resources and capabilities (Lieberman and Montgomery, 1998) as the host government, through its policies, alters the MNE's resource selection and deployment opportunities (Oliver, 1997).

\subsubsection{Second wave bargains}

A second group of foreign firms initially export products to the $\mathrm{HC}$ that compete with the first wave entrants. These foreign rival firms then decide to move onshore and begin production inside the $\mathrm{HC}$ as transplant operations. The new entrants should have the same general goals as the first wave firms: efficiency, market power and legitimacy. They also suffer from the liability of foreignness.

If the entrants come from the same home country as the incumbent MNEs, they may reap positive legitimacy spillovers (Kostova and Zaheer, 1999, p. 76), improving their bargaining power and allowing easier entry. Reputation effects also matter; foreign MNEs with high external reputations and legitimacy may be able to overcome more quickly the liability of foreignness. Firms entering from culturally distant countries are likely to suffer from liability of foreignness, being seen and treated as outsiders. Latecomers may therefore have to offer more FSAs to the HC in return for market access and invest in legitimizing activities.

The host government, assuming its main goal is international competitiveness, wants to secure the outsiders' investments, particularly if their FSAs are strong and offer potential complementarities with the HC's resources. New entrants also offer the "fresh winds of competition," which might stimulate efficiency and strategic asset-seeking strategies by the 
incumbents. The latecomers are likely to argue for national treatment; they will want the HC to guarantee a level playing field (parity or superior access relative to the first movers, for example, through locational subsidies) and to abide by international commitments. This implies governance differentiation (adding new modes) by the HC will be difficult since the outsiders will be cognizant of the results of earlier bargains between the first movers and the host government.

Will the first wave firms see the new entrants as competitors or supporters? Chen (1996, p. 104) defines competitors as firms that operate in the same industry, offer similar products, and target similar customers. Supporters, on the other hand, provide upstream (e.g., parts suppliers) or downstream (e.g., customers) linkages to the first movers. We assume the second wave MNEs are competitors and leave the supporters case for Section 5.

Chen (1996) argues that the probability of competitor firms engaging in behaviors that consciously challenge the first wave firms depends on their awareness of interfirm relationships, motivation to act and capability of taking action. He hypothesizes that the greater the commonality of markets and the similarity of resources, the less likely is a first mover to make threats, but the more likely it is to respond to an attack. Following Chen, we hypothesize that the first wave MNEs will see the second wave as a threat rather than an opportunity. This is because the value of the insiders' government-created property-based resources will fall if the $\mathrm{HC}$ opens up the market to other firms (so the incumbents no longer have privileged access) or if the government opens up alternative sources of supply that the entrants can use to effectively offset the barriers to entry erected by the initial government policy. Differential rents from property-based resources can only be maintained if latecomers are not given the same preferential access as insiders (Oliver, 1997, p. 708). Even if the firms do not directly compete, their entry into the HC suggests a possible change in strategy, which the first wave MNEs are likely to perceive as a threat. We hypothesize that the more the latecomers are perceived as rivals and a threat, the greater should be the likelihood of attack by the first movers (Chen, 1996).

If the insider MNEs have established strong political support and personal relations with stakeholders in the HC (through relation-based resources created with domestic firms and/or local governments), it may be difficult for the host government to initiate new bargains with the latecomers that dissipate the property-based resources of the incumbent MNEs. As Argyres and Liebeskind (1999) argue, governance inseparability can arise either from previous contractual commitments and/or from changes in bargaining power of a contractual party. We thus anticipate that the HC government's room to manoeuvre will be constrained either directly by its earlier contract(s) with the first movers and/or by their increased political power. However, while Argyres and Liebeskind see governance inseparability as constraining governance differentiation (i.e., new contracts must be similar to old contracts), we anticipate constraints on governance similarity (i.e., new contracts cannot be as favorable as old contracts).

Proposition 2: The initial MNE-HC bargains of the latecomers should be less favorable than the bargains of the first movers, ceteris paribus. 


\subsubsection{Trilateral bargains}

Does MNE-HC bargaining with new foreign investors have implications for existing HC-MNE bargains with the original investors? Chen (1996) argues that the greater the resource and market commonality between two firms, the less likely is one firm to make a threat, but the more likely it is to retaliate against one. It will therefore be important to determine the degree of overlap in markets and resources between the first mover and second wave entrants. To the extent that the two groups already compete in foreign markets, we expect that the latecomers' entry should be perceived as a threat (direct competition in the first movers' market) and induce retaliation by the incumbents.

Based on these insights, we assume that the bargaining process becomes more complicated after entry by the latecomers. Both insiders and outsiders are likely to engage in economic and political activities directed at altering $\mathrm{HC}$ perceptions of their legitimacy and at changing government policies in ways that benefit them and/or harm rivals (Eden and Molot, 1993a, 1996; Molot, forthcoming). The incumbents' strategies will attempt to change government perceptions of "Who is us?" so as to prevent the entrants from overcoming their liability of foreignness and obtaining insider status (Eden and Molot, 1993a, 1996). The incumbents could exclude the new entrants from membership in industry associations, circulate position papers documenting relative contributions to the economy and present a united front to the HC. The entrants are likely to engage in legitimacy-enhancing activities such as supporting local charities, promoting advertising campaigns documenting their contributions to the local economy and developing personal relationships with local government officials.

Alternatively, each group could attempt to influence public policy outcomes directly through lobbying; this could involve modifications of existing bargains or the attempt to craft new, more favorable ones. The literature on firm lobbying and trade policy demands has important insights here. ${ }^{5}$ The insiders could lobby for policies designed to erect barriers and raise costs for the entrants. If the insiders are unsuccessful at persuading the government to deny access to the new foreign firms, they will attempt to ensure that the access is inferior to their own, in order to protect their location-bound resources. Averyt and Ramagopal (1999) argue that the incumbent firms are likely to engage in strategic disruption, i.e., the use of offensive corporate strategies designed to disrupt the strategies of rival firms. Examples of strategic disruption could include demands for industry-specific or international policies that would close the local market and/or to improve the insiders' access both to their own market and to the home market of the foreign firms.

Both groups can also engage in economic strategies. These can be efficiency-based; that is, designed to increase a firm's competitiveness vis à vis its rivals through policies such as rationalizing production and technology upgrading. Alternatively, the insiders could adopt shelter-based strategies, designed to protect themselves from market competition, erect barriers to entry and extend their market power (Rugman and Verbeke, 1990).

\footnotetext{
5 See, for example, Milner and Yoffie (1989), Rugman and Verbeke (1990, 1998), Eden and Molot (1993a, 1996), Boddewyn and Brewer (1994), Shaffer (1995), Goodman et al. (1996), Keillor et al. (1997), Crystal (1998), Hathaway (1998) and Alt et al. (1999).
} 
Are the first movers likely to seek protectionist policies or focus on efficiency improvements? Transaction cost economics suggests that firms with specific (less mobile) assets will react to international competition by lobbying governments for protection (Alt et al., 1999). If the FSAs of the first movers are location bound (e.g., relation-based assets and protected access to $\mathrm{HC}$ resources), a protectionist response is likely.

Additional insights into this question come from seeing how domestic firms respond to inward FDI. Goodman et al. (1996) hypothesize that inward FDI changes the configuration of interest groups for and against trade barriers. Domestic import competing firms are assumed to favor trade barriers. Where FDI is import substituting, the interests of MNEs and domestic firms will coincide in favoring protection. On the other hand, import-complementing FDI will cause MNEs to favor free trade because tariffs can lead to retaliation and raise the MNEs' cost of imported inputs. As long as FDI stays small, domestic firms' preferences should dominate trade policy debates, but as FDI rises, the demand for protection will increasingly depend on whether FDI is import substituting or complementary. If existing FDI is import substituting and new foreign entrants appear, the incumbent MNEs should join with the domestic firms in lobbying for protection. We therefore propose that:

Proposition 3: Subsequent MNE-HC bargains will be increasingly conflictual; as long as the latecomer MNEs have not attained legitimacy parity with the first movers, bargaining outcomes favor the first movers, ceteris paribus.

Mayer (1998) points out the role that a second government can play in the negotiations. Each domestic group has policy preferences bounded by the minimum they are willing to accept and the maximum they hope to attain. The zone of potential agreement maps the area where the preferences of the individual groups overlap. The government can strike a successful bargain if its policies fall in the zone of potential agreement. Mayer argues that where the bargaining process is international, involving two governments as well as domestic firms (e.g., NAFTA), the domestic zone of potential agreement inside each country determines the potential range of agreement at the international level.

Extrapolating from Mayer's argument, we hypothesize that existing home-host country relations should create governance inseparability that constrains the independent actions of the HC government. In addition, if the home government(s) of either the first or second wave entrants should intervene on behalf of its own firms, the bargaining process should become more complex, involving two-level games. Similar to strategic trade policy, the home government can engage in strategic FDI policy whereby the government intervenes on behalf of its domestic firms and, through credible threats (e.g., withdrawal of reciprocal market access) and/or the use of external institutions (e.g., launching a complaint at the WTO), alter bargaining outcomes (Yu and Eden, 2001). Such triangular diplomacy (Stopford, 1994) suggests our fourth proposition:

Proposition 4: Strategic interventions by a home country government on behalf of its MNEs shift bargaining outcomes in their favor, depending on the political and economic importance of the home country to the HC government, ceteris paribus. 
Domestic and international institutions can constrain both parties' options, either through previous contractual commitments or changes in bargaining power (Argyres and Liebeskind, 1999). Crystal (1998) examines the political demands of US firms in response to inward FDI, finding that incumbents often do not lobby for restrictions against inward FDI, even where their profits are negatively affected, because domestic institutions and norms constrain local firms in exercising their interests. This suggests that institutions may constraint MNE behavior, at least for first wave MNEs. International institutions can also constraint HC governments; for example, BITs set out the rules under which home and host governments must treat MNEs, and regional and multilateral agreements (e.g., NAFTA) with FDI regulations can constrain government actions (Eden, 1996; Ramamurti, 2001). Therefore, we propose:

Proposition 5: Membership in domestic and international institutions causes governance inseparability, constraining trilateral bargaining outcomes, ceteris paribus.

\section{A case study of bargaining in the Canadian auto industry}

In this section, we test the five propositions of our trilateral bargaining model in a study of public policy decisions in the Canadian automotive industry, from the tariff-jumping entry of Ford Motor in 1904 to the present. We group and analyze the bargaining cases according to our three time periods: first wave, second wave and trilateral bargains.

\subsection{First wave bargains}

\subsubsection{First wave entry (early 1900s)}

The basis for foreign ownership of the Canadian auto industry is the 1879 National Policy, which imposed high tariffs on imported manufactured goods to encourage domestic manufacturing. Tariffs on autos ranged from $22.5 \%$ to $35 \%$, with Canada-Britain trade receiving preferential, reciprocal access under the Commonwealth preferences system. By assembling cars in Canada, a US firm could avoid the 35\% Canadian tariff on US-made autos destined for sale in Canada, and export Canadian-made cars to the Commonwealth at duties significantly less than faced by US exports. Ford was the first US MNE to jump the Canadian auto tariff, arriving in 1903. By 1929, the Big Three controlled almost $85 \%$ of the Canadian auto industry. Not surprisingly, given the Canadian tariff structure, approximately $40 \%$ of the Big Three's production in Canada was exported, two-thirds of that to other British Commonwealth countries.

As early as 1926, Canada began providing duty drawbacks for imported parts, as long as the parts were not made in Canada or the autos produced with these parts contained at least $50 \%$ Canadian content. This allowed the Big Three to import US-made parts at low tariff rates, while still using high tariffs on finished vehicles to discourage imports and encourage Canadian assembly. In 1936, the rates on vehicles were reduced to $17.5 \%$, with the British Preferential tariff dropping to zero. Parts could be imported duty free if Canadian-made parts represented $60 \%$ of vehicle costs. 
Throughout the 1950s, the industry stagnated. In response to growing balance of payments difficulties, in 1960, the Canadian government appointed the Bladen Commission, which recommended higher tariffs and tighter content requirements to protect the domestic industry. In 1962-1963, the government responded by introducing higher duties on imported parts, with duty remissions tied to increased exports of auto products. These trade-balancing requirements were seen in the US as export subsidies. US parts manufacturers responded by asking the US government to impose countervailing duties. These were the background conditions that precipitated negotiation of the 1965 Canada-US Auto Pact.

\subsubsection{Canada-US Auto Pact (1964-1965)}

The Auto Pact was a three-way negotiation between the Canadian and US governments and the auto industry (the Big Three, the United Auto Workers and independent parts producers). The two governments came to the table with a similar goal- to improve industry efficiency and protect jobs - but with different policy proposals. The US government wanted sectoral free trade in autos and parts; Canada wanted performance requirements to ensure that vehicle assembly remained in Canada. The Big Three wanted to improve plant efficiency through longer production runs, take advantage of lower Canadian labor costs and increase vehicle sales in Canada. Independent parts producers and Canadian labor opposed the Auto Pact.

The outcome was a free trade agreement for auto producers, but the Pact operated differently in the two countries (Eden and Molot, 1993b; Thomas, 1997; Molot, forthcoming). Vehicles and parts from Canada could be imported into the US duty free if they contained a minimum of $50 \%$ North American (Canada and/or US) content. In Canada, vehicles and parts could enter duty free from any location if they were imported by a 'qualifying' Canadian manufacturer. To be so designated, a producer had to be producing vehicles or parts in Canada in 1964 and meet certain minimum production and Canadian value-added (CVA) requirements. The Big Three also signed Letters of Undertaking in which they committed themselves to increasing their CVA in each model year by at least 60 percent of the growth in Canadian sales. In effect, the Big Three received duty-free access to the whole North American market in exchange for performance requirements.

\subsubsection{Analysis of the first wave bargains}

Our first proposition argues that the initial entry by foreign MNEs involves HC-MNE bargaining that gives the MNEs privileged access to HC property-based location-bound resources in return for the transfer of nonlocation-bound FSAs to the HC. Initial bargains favor the entrants where the indigenous industry is small, the HC wants the FDI, and the alternatives favor the MNEs. We find support for this in the Canadian auto industry, which historically has been dominated by foreign firms. With the early takeover of Canadian-owned assemblers, the Big Three achieved insider status with protected access to the Canadian market.

Protected by high tariff walls, their subsidiaries in the 1950s were high-cost miniature replicas of their US parents. The Big Three and the Canadian (and US) governments had 
similar interests in pursuing an automotive free trade zone, and the issue was of high salience to both parties. The Auto Pact provided privileged access to 'qualified manufacturers' that were allowed to import parts and vehicles duty free as long as they met certain production and sourcing conditions. The Big Three were able to rationalize production on a North American basis, achieving greater efficiency, employment, trade flows and income. From its inception, the Auto Pact became the cornerstone of Canadian automotive policy.

\subsection{Second wave bargains}

\subsubsection{Voluntary export restraints (VERs) (1981-1985)}

In 1981, Canada followed the US in limiting Japanese vehicle exports to Canada through a VER agreement with Japan. The Big Three, Canadian-based parts producers and Canadian labor all supported the agreement. In 1985, when it became clear that the US government would not request the renewal of the marketing agreement, Canadian auto industry stakeholders argued strongly that the VERs should be retained.

Canada and the US negotiated VERs with Japan at the urging of the Big Three to protect their production, sales and employment. Canada had a second objective, to encourage new investment in vehicle production and indirectly, the purchase of more Canadian-made parts. The Canadian VER was therefore also designed to induce tariff-jumping FDI by Japanese assemblers. It also opened a window for Hyundai, a Korean auto assembler, to increase its Canadian sales at the expense of Japanese-produced vehicles.

\subsubsection{Entry of the transplants (mid-1980s)}

Both the US and Canadian VERs induced the Japanese assemblers to move to North America in the mid-1980s. The Canadian government made a conscious effort to attract Asian assemblers. While formal Auto Pact status was not offered (the new entrants could not meet the Auto Pact's requirements), Canada provided Honda and Toyota with duty drawbacks and duty remissions that essentially allowed them to import parts duty free if certain export performance levels were attained. The Canadian government signed a Memorandum of Understanding (MOU) with each company outlining specifically designed duty remission and drawback schemes. The expectation was that, over approximately 7 years, the transplants would increase Canadian vehicle production and parts purchases sufficiently to qualify for Auto Pact status.

Once the Asian transplants began using the duty drawback and remission programs to import Asian automobiles for the North American market, the US government made known its displeasure with the MOUs. By treating the transplants on a de facto equivalent basis with the Big Three, the US government felt Canada was encouraging the Japanese transplants to use Canada as a 'back door' to the US market. As transplant exports increased from Canada to the US, the import penetration threat became a reality and US government complaints grew more vociferous. The duty drawback and remissions schemes not only encouraged cheaper Japanese exports to the US market via Canada, but also benefited Japanese rather than US parts producers, a double affront in US eyes. Transplant production also contributed to 
excess capacity in North America. For all these reasons, the duty rebates were contentious. If the FTA negotiations had not occurred, US pique might have eventually put the Auto Pact at risk.

\subsubsection{Analysis of the second wave bargains}

Our second proposition argues that the latecomers will receive less favorable bargains that the first entrants, particularly if the first wave MNEs are seen as insiders, the latecomers are seen as a threat by the incumbents and the $\mathrm{HC}$ is constrained by previous bargains.

Until the Asian producers formally invested in Canadian plants, they were clearly treated as outsiders by the Canadian government. The VERs offered an opportunity for the Big Three to achieve higher levels of protection against Asian imports, and thereby increase the value of their own property-based resources. While sensitive to the declining competitive position of the Big Three, the Canadian government's decision was also designed to induce tariffjumping behavior by the outsiders that could, if followed, harm the Big Three. Thus, both parties saw benefits from protectionism, but for different reasons.

The initial entry of the Japanese transplants provided the first wedge between the Big Three and the Canadian government. The transplants lobbied for a level playing field, giving them the same duty-free status as the Big Three. The Canadian government refused to grant the latecomers Auto Pact status because the firms could not fulfill the Pact's conditions. However, the latecomers were given the de facto equivalent of Auto Pact status, while they developed the capacity to meet its requirements.

Our second proposition argued that MNE-HC bargains with latecomer firms would be less favorable than the bargains achieved by the first movers because governance inseparability would constrain the host government's ability to negotiate new contracts with the latecomers. It is clear that the Auto Pact constrained the Canadian government's options. With the transplants pressing for a level playing field and the government wanting new FDI and jobs and technology upgrading, Canada chose to grant the equivalent of Auto Pact status to the Asian transplants. The latter secured an outcome almost as favorable as that achieved by the incumbents. We proposed, however, that the bargains would favor the insiders, which they did not.

Why did the second wave bargains initially favor the latecomers? First, the Big Three did not oppose the arrangements negotiated by the Canadian government and thus did not invest in lobbying against the newcomers. Second, both the entrants and the Canadian and Ontario governments had a vested interest in obfuscating the bargaining outcomes through secrecy both before and after the negotiations, which limited the comparability of the bargains and lessened the governance inseparability constraint.

The original latecomer MNE-HC bargain began to obsolesce in the eyes of the Canadian government once the US government began to complain about the MOUs. With Canada so heavily linked to the US through trade and FDI flows, the US government's ability to withhold market access and financial capital was a powerful bargaining lever. Thus, intervention by a home country (US) government on behalf of its MNEs further constrained the bargaining set for Canada, as suggested by our fourth proposition. 


\subsection{Trilateral bargains}

\subsubsection{Canada-US Free Trade Agreement (FTA) (1984-1989)}

The FTA negotiations began shortly after the first assembled-in-Canada vehicles began rolling off the assembly lines of the Asian transplants. The autos chapter of the FTA built on, and attempted to address some of the tensions generated by, the Auto Pact (Eden and Molot, 1993b; Johnson, 1993; Molot, forthcoming). The US government was unhappy with the Canadian production safeguards in the Auto Pact (Canada saw them as permanent, the United States as transitional) and with the Canadian duty drawback and remissions programs given to the Asian transplants.

By the mid-1980s, the Big Three were facing strong competition from Asian producers, both from imports and North American-assembled vehicles. The first wave producers therefore wanted the FTA to protect and enhance their own share of the North American market at the expense of the newcomers (Eden and Molot, 1993a). By increasing the level of North American content required to permit duty-free trade in vehicles, they hoped to strategically disrupt the production, trade and sales patterns of the Asian transplants and raise their costs (Averyt and Ramagopal, 1999). The Big Three also wanted a clear statement that Auto Pact status would not be extended to the Asian MNEs. The US government and parts producers supported the Big Three, demanding a $60 \%$ rule of origin and no extension of Auto Pact status.

Although the Canadian government was sensitive to the situation of the Asian MNEs, it did not actively consult them. The government did, however, attempt to balance the demands of both waves of foreign assemblers by lobbying for $60 \%$ North American content level (favoring the insiders) and the retention of duty remissions (favoring the outsiders).

The FTA outcome clearly favored the Big Three. No new firms in Canada, with the exception of CAMI (a joint venture between GM and Toyota), were to be granted Auto Pact status unless they qualified by January 1989 (none did). New, more complex rules of origin were introduced based on $50 \%$ North American content. Duty drawback schemes were to be eliminated by January 1994, which meant that the transplants would have to pay the Canadian tariff on imported parts. ${ }^{6}$

The Asian transplants clearly lost in this bargaining round. Once they realized that the FTA had enshrined the two-tier character of the Canadian assembly industry, they expressed their concerns to the Canadian government. They also realized that not lobbying for their interests in the FTA negotiations was a mistake, and did not repeat the error in the NAFTA negotiations.

\subsubsection{Honda Civic dispute (1990)}

The application of the FTA rules of origin was both technical and controversial. The bestknown dispute was the unsuccessful attempt by the US Customs Administration to levy a 2.5\% tariff on US imports of Honda Civics from Canada on the grounds that the vehicles contained insufficient North American content. The Canadian government strongly supported

\footnotetext{
${ }^{6}$ We consider the tariff on imported parts in Section 4.3.3.
} 
Honda's position, fearing that if Honda lost the case, the Asian assemblers might shift production to the United States.

\subsubsection{NAFTA (1991-1994)}

By the time the NAFTA negotiations began in 1991, competition between the insiders and outsiders had intensified because the transplants now had production capacity in all three countries. Once again, the negotiations over the autos provisions were difficult (Eden and Molot, 1993b; Mayer, 1998). The Big Three saw the NAFTA negotiations as another opportunity to strategically disrupt the Asian transplants by pushing for higher North American content rules. Concerned about Mexico becoming an export platform for cheaply assembled Asian vehicles, the insiders pressed for the creation of a two-tier system in Mexico, similar to the Auto Pact. They also wanted liberalized Mexican policies for themselves, but not for the latecomers. The US government supported the Big Three's positions during the negotiations.

In contrast to the FTA talks, the Asian transplants were seen by the Canadian government as actors with a stake in the outcome and invited to discussions over Canada's bargaining position (Molot, forthcoming). The transplants wanted clearer rules of origin, no increase in content requirements, and termination of the two-tiered status of the Auto Pact. Canada, which did not differentiate among vehicle assemblers, wanted the content level to remain at $50 \%$. In the end, Canada accepted the higher North American content levels.

The NAFTA autos chapter built on the autos provisions of the FTA and extended the provisions to Mexico. There were three important changes to the rules of the game in autos. First, the North American content requirement was raised to $62.5 \%$ for vehicles and parts. Second, and of particular relevance to the transplants, the method of calculating North American content was changed to net cost, which meant that actual content had to be tracked for parts and, thus by implication, vehicles, through the production chain. Third, NAFTA retained the January 1998 expiration date for export-based duty remissions, but gave the transplants 2 more years of breathing room by extending duty drawbacks until January 1996.

\subsubsection{Removing the parts tariff (1993-1997)}

Throughout the NAFTA negotiations, the Asian transplants pressed the Canadian government to reduce the tariff on imported parts, then $9.2 \%$. The government recognized that it had to find a way to continue meeting its commitment to the transplants in the MOUs for duty-free entry of parts. In December 1993, a few weeks before NAFTA took effect, the government eliminated tariffs on engines and transmissions and reduced the duty on most other parts from $9.2 \%$ to $2.5 \%$. In December 1995, less than a month before the expiry of the duty drawbacks program all tariffs on auto parts were removed. In late 1997, the Canadian Parliament passed legislation to permanently eliminate all duties on imported vehicle parts.

The Big Three were extremely unhappy with the temporary and then permanent elimination of the parts tariff. Corporate executives suggested the changes undermined the value of the Auto Pact, reduced the incentive to purchase Canadian parts, removed a bargaining chip that Canada could use in negotiations with other countries to improve market 
access for Canadian-built parts and vehicles, and was out of step with the US (which retained a $2.5 \%$ parts tariff). Their complaints were ignored (Molot, forthcoming).

\subsubsection{The vehicle tariff and the WTO decision (1996-2001)}

The debate over the tariff on vehicles imported by non-Auto Pact members began in May 1996 when the government initiated an industry review (Industry Canada, 1998). For both sets of stakeholders, the issue was one of principle: would Canada honor its long-standing commitment to the first entrants and reward the insiders for the huge investments they had made in Canada over the past century by retaining the Auto Pact, or would the government level the playing field and treat all assemblers, regardless of origin, the same way?

The Asian transplants lobbied hard for removal of the vehicle tariff. The Big Three, the Canadian Auto Workers and the Automotive Parts Manufacturers Association opposed any change in the status quo, arguing that tariff removal would lead to more vehicle imports and reduced Canadian vehicle and parts production. The 1998 take-over of Chrysler by DaimlerBenz and the purchases of Jaguar and Volvo by Ford enhanced the value of Auto Pact membership. These mergers and acquisitions meant that high-end European vehicles were eligible to enter Canada duty free, as a result, heightening the frustration of the Asian transplants.

In 1997, during the Canadian automotive policy review process, the Japanese government intervened for the first time, complaining of unfair treatment and lobbying on behalf of its auto assemblers for removal of the vehicle tariff. Japan identified the vehicle tariff as a major trade irritant, hinting that it was prepared to take the dispute to the WTO if Ottawa continued its two-tier policy.

In June 1998, the Canadian government announced that it would retain the vehicle tariff. Within weeks of the decision, Japan and then the European Union announced they would take Canada to the WTO. Both governments argued that the Auto Pact contravened Canada's WTO commitments, citing three violations: (a) the right accorded only to Auto Pact members to import cars duty free from anywhere in the world; (b) the CVA requirements of the Auto Pact, which provided an incentive to purchase or use domestic parts and materials over imported ones; and (c) the Pact's production-to-sales requirements.

Both the interim and final WTO decisions in late 1999 found against Canada. The government appealed, but the May 2000 appellate body determination largely upheld the findings of the WTO panel. Bargaining among the auto firms and the government continued after the announcement of the WTO decision. The transplants continued to press for the removal of the tariff; while the Big Three wanted both the vehicle and parts tariffs reinstated, in effect, scrapping the Auto Pact.

Canada had to decide whether to scrap the vehicle tariff (as demanded by the Asian transplants) or the Auto Pact (the centrepiece of Canadian auto policy for the last 35 years). Under pressure from the Big Three, Canada argued that the change in tariff regime would require at least a year's transition. Japan and Europe insisted that the changes should be implemented quickly. The WTO gave Canada until March 2001 to act on the panel decision. In late 2000, the Canadian government announced that it would terminate the Auto Pact in mid-February 2001. All assemblers importing vehicles into Canada will have to pay the $6.1 \%$ 
tariff. The government's decision clearly favored the Big Three, but at the cost of dismantling the longest run trade policy in Canadian history (Molot, forthcoming).

\subsubsection{Analysis of the trilateral bargains}

Our third proposition argues that subsequent bargains between the HC and foreign MNEs (insiders and outsiders) should be more conflictual, particularly when the two waves of MNEs see themselves as rivals and the incumbents lobby for protectionist policies designed to disrupt the strategies of the latecomers. As long as the latecomers still suffer from the liability of foreignness and have not attained legitimacy parity with the first movers, we argued that bargaining outcomes should favor the incumbents.

We find strong evidence that the insider firms did turn increasingly protectionist after the entry of the Asian transplants. The Big Three lobbied hard for high rules of origin in the FTA and NAFTA (Mayer, 1998, pp. 155-162). To the extent that their own products are sourced in North America, the parts and vehicles tariffs do not affect them, and in fact, the vehicle tariff offers additional price protection and producer surplus gains. Tighter rules of origin, however, impose real costs on the Japanese transplants.

An illustration may be helpful here. To better understand the difficulties of trilateral bargaining, it is useful to conceptualize the Big Three and the transplants as two strategic groups in the Canadian auto industry. Assume that the Canadian market for vehicles is satisfied from only three sources: local production by the Big Three $\left(Q_{\mathrm{Big}}{ }_{3}\right)$, Japanese transplant production in Canada $\left(Q_{\mathrm{JC}}\right)$ and Japanese imported vehicles $\left(Q_{\mathrm{JM}}\right)$. This is illustrated in Fig. 2.

We construct the Canadian demand for Asian autos by horizontally subtracting the Big Three's supply curve from Canada's demand curve (i.e., the intercept of $D_{\mathrm{JC}}$, the demand curve for Asian autos, point $b$, is directly across from point $a$ and the two curves intersect at the $x$-axis). We assume the supply of Asian imports is perfectly elastic at the world price $\left(P_{\mathrm{J}}\right)$. Canada levies tariffs at MFN rates on imported parts and vehicles from outside North America, with the tariff on vehicles being higher than on parts. The Big Three pay neither tariff since they are qualified Auto Pact manufacturers. The Japanese transplants, initially because of their MOUs with their Canadian government, are also able to escape the parts tariff through the duty drawback and remission schemes, but cannot totally escape the vehicle tariff. The producer's price of vehicles in Canada is therefore the world price plus the vehicle tariff, $P_{\mathrm{J}}+T_{\mathrm{V}}$.

Total sales by the Asian transplants are determined by point c (where $D_{\mathrm{JC}} \operatorname{crosses} P_{\mathrm{J}}+T_{\mathrm{V}}$ ) and measured by the distance $f c$. Transplant production is determined by point $e$ (where $S_{\mathrm{JC}}$ crosses $P_{\mathrm{J}}+T_{\mathrm{V}}$ ) and measured by the distance $f e$. Japanese imports are therefore measured by the distance $e c$, which is $f c$ minus $f e$. Big Three sales are determined by point $d$ (where $S_{\text {Big } 3}$ crosses $P_{\mathrm{J}}+T_{\mathrm{V}}$ ) and measured by the distance $f d$, which by construction equals the distance $c g$. Canadian sales therefore consist of three components: transplant production ( $f e$ ) plus transplant imports $(e c)$ plus Big Three sales $(c g)$. The transplants pay tariff revenues on their imported vehicles; total revenues equal the rectangle echi.

Now, conceptualize the transplant supply curve in Fig. 2 as the vertical sum of two components: the cost of auto parts (domestic and imported) and the costs of assembly. Tighter 


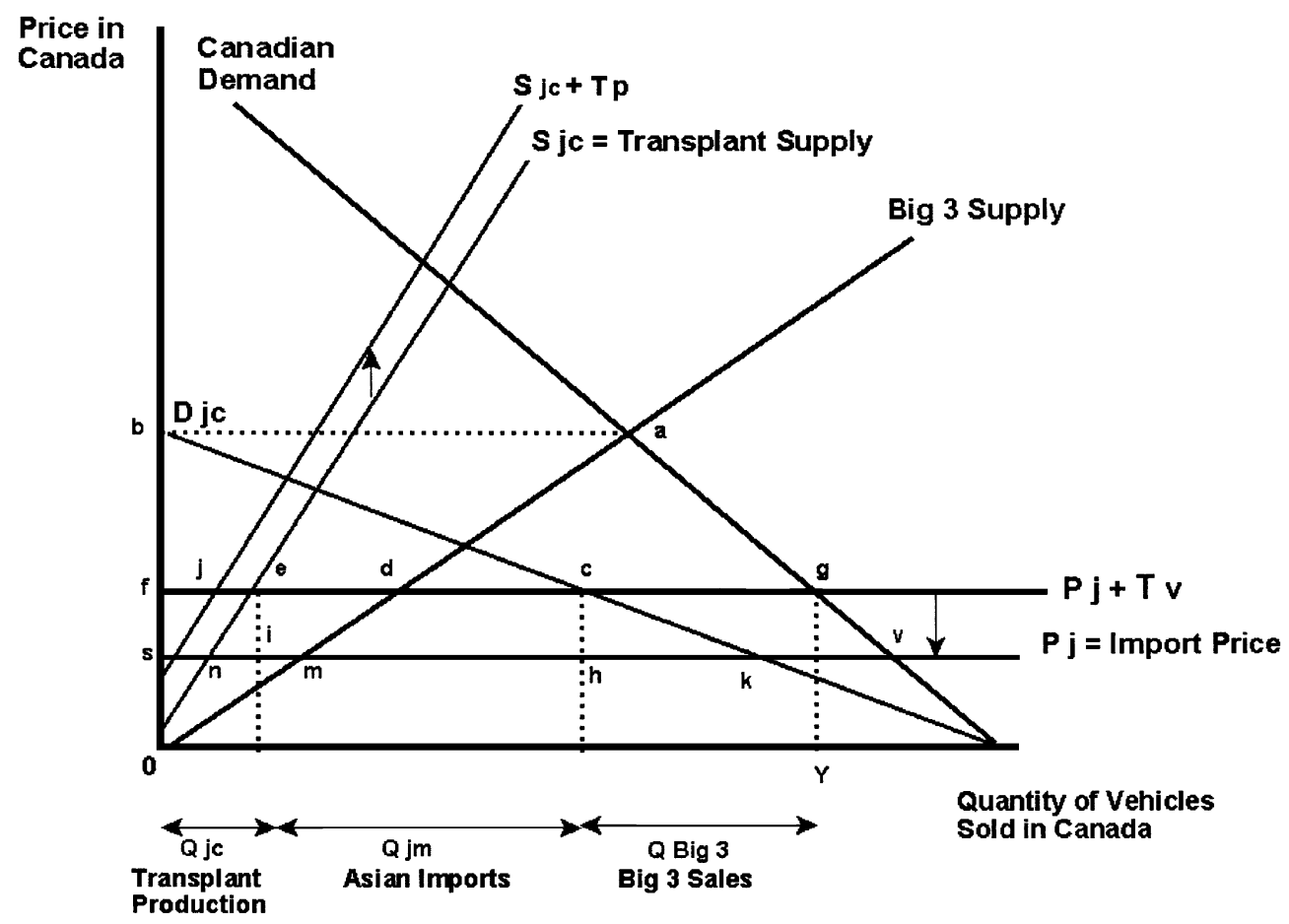

Fig. 2. Impact of the parts and vehicle tariffs on the Canadian auto industry.

rules of origin raise overall parts costs, which is equivalent to an upward shift in the transplant supply curve, for two reasons: the transplants' choice of parts suppliers is restricted, and the building of expensive power train plants producing engines and transmissions may be required (Crystal, 1998). By enforcing tight rules of origin in the FTA and NAFTA, the Big Three are therefore be able to aggressively disrupt the strategies of their Japanese competitors and substantially increase the transplant costs of penetrating the North American market (Averyt and Ramagopal, 1999). In addition, in fact, the tighter rules of origin have induced the Asian transplants to build engine and transmission plants in North America in the early 1990s.

The NAFTA eliminated the duty drawback and remission schemes for the Asian transplants. This was equivalent in Fig. 2, to an upward shift in the costs of assembling vehicles in Canada for the Asian transplants only, because they would be required to pay the parts tariff. Ceteris paribus, the new volume of transplant production would have fallen to point $\mathrm{j}$, with imported Asian vehicles rising to the distance jc.

The NAFTA enshrined a two-tier assembly industry in Canada and the US with the Big Three maintaining their first-tier Auto Pact status. The one exception was CAMI, the joint venture between General Motors and Toyota, which was also granted this status. This exception suggests a qualification to our third proposition: if a second wave MNE is able to connect with the insider firms through strategic alliances or joint ventures, the outsider MNE can create relation-based resources that increase its relative bargaining power, and offer legitimacy and efficiency gains. Moran (1973) found a similar result with Kennecott in Chile. 
Fig. 2 can also help explain why the Canadian government's decisions in both the Honda case and the parts tariff favored the Asian transplants, rather than the Big Three, outcomes contrary to Proposition 3 of our trilateral bargaining model. Either a sufficiently high parts tariff on non-North American imports or a US tariff on transplant vehicles (e.g., Honda Civics) exported from Canada to the US could have raised Canadian costs so high as to force the transplants to close their plants and exit Canada.

We argue that the Honda case was a turning point in the sequential MNE-HC bargaining process in Canada when the Canadian government's perceptions of the transplants switched from seeing them as outsiders to insiders. The transplants had achieved organizational legitimacy - insider status - by delivering on their MOU commitments. By supporting Honda in 1991 and eliminating the auto parts tariff after NAFTA, the Canadian government avoided the loss of production and employment that would have followed had the transplants been hit by these tariffs. Thus, the Canadian government's need for skilled jobs and technology transfers in a time of high unemployment increased the resource complementarity and political accommodation "building blocks" of MNE-HC relations (Luo, 2001). In addition, governance inseparability constrained the Canadian government since the MOUs had promised the Asian transplants duty-free status in return for investment and jobs. Lastly, in the Honda Civic case, the Big Three were not directly affected by the Canadian government's intervention and so did not directly lobby for or against it. ${ }^{7}$

Our fourth proposition hypothesizes that the home country government could influence bargaining outcomes in favor of its MNEs. We also find evidence of this in our case study, though the capacity to do so was a function of the importance of the home country market and thus its bargaining clout. While the Canadian government attempted to treat the Asian transplants as insiders the FTA and NAFTA negotiations brought in the US government, the home country standing behind the Big Three. Under these circumstances, it is not surprising that subsequent $\mathrm{HC}-\mathrm{MNE}$ bargains favored the incumbents. Although Japan did intervene to try to push the Canadian government to remove the tariff on vehicles imported by non-Auto Pact members, its intervention, and indeed threats to take Canada to the WTO, had no impact in the face of countervailing claims by the Big Three and the US government. Thus, our fourth proposition - that the home government's intervention can strategically shift the bargaining outcome in favor of its MNEs - is borne out by our cases.

The last of our cases, the decision to retain the vehicle tariff, illustrates the impact that even a home country with limited market clout can have on MNE-HC negotiations. At stake was the major remaining distinction between the Big Three and the transplants: the ability to import duty free into Canada cars assembled offshore. The initial outcome was a win for the Big Three, in accordance with our third proposition. However, the Japanese government immediately intervened on behalf of its assemblers, took Canada to the WTO, and won with a finding that the Auto Pact was discriminatory. Thus, intervention by Japan, through resort to an international organization to which all three countries were members, was able to strategically alter the bargaining calculus, at least in the short run.

\footnotetext{
${ }^{7}$ On the other hand, in the parts tariff case, the Big Three strongly objected to its removal, but did not offer any concessions that would have induced the government to retain the tariff.
} 
To understand the decision that faced Canada when the WTO ruled against it and found the Auto Pact discriminatory, it is important to recognize that the Big Three benefited significantly from the tariff structure then in place. They imported small numbers of primarily luxury cars, whereas the transplants were responsible for $90 \%$ of all imported vehicles. Under the Auto Pact, the Big Three did not pay the vehicle tariff on imports of Mercedes-Benz, Jaguars or Saabs, but at the same time, the insiders enjoyed protection due to the vehicle tariff, which enabled them to charge higher prices for vehicles all along the price spectrum. The gain in producer surplus to the Big Three from enshrining the Auto Pact's two-tiered status vis à vis the Asian assemblers in terms of the vehicle tariff can be represented by the trapezoid $f d m s$ in Fig. 2. This trapezoid represents rents to the location-bound property-based resources enjoyed by Auto Pact assemblers.

Canada was faced with two possible policy responses to the WTO decision. Under the first, it could remove the vehicle tariff so that none of the assemblers would pay duty on imported vehicles; as a result, the price would fall to $P_{\mathrm{J}}$, transplant production would fall to point $n$ (the distance $s n$ ), Big Three production would fall to point $m$ (or the distance $s m$ equals $k v$ ) and Japanese imports would expand to the distance $m k$. Thus, domestic production in Canada, by both the Big Three and the transplants, could decline, the decline being larger or smaller depending on the cost-price differential between domestic and offshore production.

The second alternative was to scrap the Auto Pact, making all assemblers pay the tariff on imported vehicles that do not meet NAFTA rules of origin. As a result, the Big Three's resource rents on (their few) imported vehicles would disappear, but they would continue to receive protection in terms of North American-produced vehicles. This would minimize their costs, but would also deprive Canadian consumers of the benefits from lower priced imports, with the transplants being left more or less unaffected.

Our third proposition implies that Canada should have chosen to respond to the WTO decision by imposing the vehicle tariff on the Big Three, rather than removing it for everyone, because reinstating the vehicle tariff (while clearly second best) offered better protection for the insiders' property-based resources. This is exactly what happened. The Canadian government chose to scrap the Auto Pact, benefiting the insiders at the expense of the latecomers. Even after the intervention of the Japanese government, Canada chose a policy outcome that favored the Big Three. We conclude that where two home governments become involved in a trilateral MNE-HC bargaining process, the final outcome should favor MNEs from the country with the stronger economic and political power, as argued in Proposition 4.

Our last proposition, that institutions can constrain $\mathrm{MNE}-\mathrm{HC}$ bargaining outcomes, is also illustrated by several of our cases. The Auto Pact was the institution sine qua non constraining the Canadian government's policy making from 1965 onwards; both the FTA and the NAFTA built on and enshrined the main features of the Auto Pact. Canada's membership in another institution, the WTO, forced the Canadian government to remove the vehicle tariff. Who would have guessed that the WTO - an institution first proposed by Canadian trade negotiators during the Uruguay Round-would be the death knell for Canada's oldest and most revered trade policy? Thus, government-to-government (upper-tier) bargains can establish overall rules of the game, which then constrain MNE-HC bargaining in specific issue areas (Ramamurti, 2001). 


\section{Discussion}

Our theoretical model is somewhat specialized in that it makes a variety of assumptions that influence the propositions and outcomes. We need to relax some of these assumptions and determine how our conclusions would change in order to demonstrate the robustness of the model.

First, we have assumed that the first movers attain insider status within the HC before second wave entry. However, suppose the first movers become an entrenched monopoly and focus on rent extraction rather than efficiency and legitimacy goals. Or, suppose the first entrants never overcome their liability of foreignness. In these cases, the new entrants will be welcomed as bringing the "fresh winds of competition," and the second wave bargains should be at least as favorable to the latecomers as the original bargains.

Second, we could reverse the ownership and contemplate a situation in which the Japanese firms were the insiders and US firms the latecomers. In this situation, we expect that Proposition 4 about the relative ability of a home government to shift the bargain in favor of its own MNEs would still hold. The more powerful US government with its larger market size and closer political ties to Canada should be able to influence the MNE-HC bargaining process in a way that the less powerful Japanese government could not.

Third, the timing of entry matters. The longer the period between first wave and second wave entry, the more time the first movers have to build their location-bound resources in the HC. The legitimacy wedge (difference in liability of foreignness) between the first and second wave entrants should be positively related to the timing gap. The greater the wedge, the more likely that second wave bargains and trilateral bargains will favor the first movers, ceteris paribus.

Fourth, we have assumed that the HC negotiates with foreign MNEs. However, what is key to our model is the difference in the legitimacy status of the first and second entrants, not whether they are foreign or national. We assume first movers achieve insider status sooner, which conditions subsequent bargains to be more biased in their favor. If the first movers are local firms, they are insiders par excellence and should receive even more favorable bargains than foreign entrants.

Fifth, we assumed that the first movers and latecomer firms are competitors. The higher the degree of rivalry between the two groups, the more aggressive the strategies we expected the first movers to exert against the latecomers. Assume, instead, that the two waves cooperate with one another. For example, the entry of foreign auto assembler firms is generally followed by upstream parts and components suppliers, moving close to the assemblers in order to participate in a lean production-based system. In such cases, one would expect the entry bargain extracted by the first movers to be even more favorable since they are able to promise more employment and investment from the second wave entrants. The locational tournaments that occur as individual governments fight to have auto MNEs locate in their jurisdiction are well documented (Thomas, 1997). If the second wave entrants bring technology spillovers that benefit the first mover firms, the appropriate response by the insiders could also be cooperative, as they seek to take advantage of the shared technology by partnering with the latecomers. Lastly, we could have assumed that the two waves of firms may compete in some 
issue areas (e.g., product markets), but cooperate in others (e.g., fuel emissions and safety regulation), leading to more complicated competitive behavior (Chen, 1996).

Sixth, the number of entrants will matter to the outcome, both in total and in each wave. One could envisage a case where the numbers of firms are large and their size small, such that the HC simply establishes the rules for entry and no firm sees it as in its interests to bargain or lobby for legitimacy and/or policy changes. Our model assumes small number entry into an oligopolistic industry, which we argue is an appropriate analogy for the types of industries dominated by MNEs.

Lastly, we have assumed the firms are in the manufacturing sector. MNEs tend to congregate in oligopolistic, knowledge-based industries such as autos, electronics, pharmaceuticals and petroleum. An examination of two-wave FDI in other industries would be important to test the robustness of our propositions. It is possible that first and second wave entry into service sectors such as hotels, accounting services or internet suppliers, could lead to different outcomes. If the motivations for entry differ (e.g., seeking market access versus lower production cost locations), MNE strategies and the amount and type of privileged access afforded by the HC government are also likely to differ. Since service MNEs tend to be horizontally integrated, market-seeking enterprises, their MNE-HC bargains might be quite different from vertically integrated component assembly operations.

Our theoretical bargaining model is therefore more general than it first appears since it can be extended to take into account a variety of differences in firms (compete or cooperate? few or firms? domestic or foreign?), industries (manufacturing or services?), timing (short or long lag?) and governments (home or host? strong or weak?). In each case, relative goals, resources and constrains condition the bargaining process and affect the outcomes.

\section{Conclusions}

The purpose of this paper was to analyze sequential MNE-HC bargains with two groups of multinationals: first wave MNEs (first movers) and second wave MNEs (latecomers). Our model incorporated recent insights from the liability of foreignness, transaction cost economics, multipoint competition and the RBV literatures.

Our sequential case study of the Canadian auto industry adds new insights to the MNEstate relations literature. First, we introduce theoretical insights from the liability of foreignness, transaction cost economics, multipoint competition and the RBV literatures into the MNE-HC bargaining model. Second, our study is an example of iterative bargaining involving several MNEs and one HC over a long time period, with two-level games where the negotiations involve home and host governments. It therefore fits Shaffer's (1995) call for better qualitative research on corporate political behavior. Our analysis also demonstrates how first wave bargains constrain those that follow, whether the bargains are new or modifications. For example, the Auto Pact created an institutional property-based resource for the first movers, giving them duty-free status for parts and vehicles not available to other firms or consumers, access which they sought to protect from the latecomers. The FTA and NAFTA later became new opportunities to protect the insiders at the expense of the 
latecomers. In addition, our analysis illustrates the options and constraints faced by a $\mathrm{HC}$ anxious to secure new investment in a critical industry. In several of the bargains, the Canadian government found itself trying to balance the demands of the insiders and outsiders, each group suggesting that future FDI was contingent on a bargaining outcome in its favor. Lastly, we illustrate the strategic roles that home governments can play in shifting MNE-HC bargains towards their own firms, and the constraints that international institutions can impose on these bargains.

This paper could be extended in terms of empirical work. Our model focuses on two strategic groups, insiders and outsiders, rather than individual firms. In practice, each firm is different in terms of its mix of resources, history and institutional structure, and will therefore develop different strategies. Based on Goodman et al. (1996), we expect that MNEs with high levels of international intrafirm transfers should be more pro-trade, whereas MNEs that are primarily import competing are likely to be protectionist. Vertically integrated MNEs that obtain their inputs from offshore affiliates should prefer lower tariffs on parts and intermediate inputs, but may still prefer high tariffs on finished goods. Chen's (1996) propositions about different firm strategies based on commonality of resources and markets could be tested by comparing, for example, the behavior of Ford with GM and Toyota with Honda. A more nuanced analysis would also pay more attention to the policy demands of individual firms.

Our model could be applied to other longitudinal case studies. For example, US auto assemblers moved to Europe in the 1960s and were followed by Asian MNEs in the 1980s. This case is complicated by the presence of national champions (e.g., Renault and Fiat) in some EU countries, implying potential four-way bargaining situations that should yield more complex outcomes (Hanson, 1998). In addition, in Canada, policy outcomes were increasingly constrained by its membership in international institutions. To the extent that developing countries belong to fewer international organizations, their governments may be less constrained than OECD ones (Ramamurti, 2001). Thus, policy outcomes in MNE$\mathrm{HC}$ bargaining in developing countries may look more like the traditional OB model.

Lastly, Pauly and Reich (1997) argue that MNEs diverge in systematic ways from one another because home country institutional structures are decisive influences on MNE behaviors. MNEs from different home countries "carry the shadow" of their home institutional environment into their strategic behavior. It would therefore be instructive to examine the strategies of automotive MNEs from other home countries (e.g., Germany) to determine how behaviors differ. It would also be instructive to examine the behaviors of other US and Japanese MNEs to see if the same strategic behavior patterns demonstrated in the Canadian case occur in other industries and host countries.

In conclusion, we argue the widely held view among international business scholars that Vernon's OB model has outlived its usefulness is too pessimistic. The model can be revitalized by recognizing that MNEs and governments engage in sequential bargaining over a wide variety of industry-level policies, and that these bargains are critical for shaping insider-outside status and competitive rivalry among multinationals. Our case study of MNE$\mathrm{HC}$ bargaining in the Canadian auto industry is an attempt to demonstrate the value of this approach. 


\section{Acknowledgements}

Earlier versions of this paper were presented at annual meetings of the Academy of International Business and the International Studies Association. The research assistance of Douglas Thomas and Rodney Lever and the financial assistance of the Texas A\&M CIBER are gratefully acknowledged. Helpful comments were received from Nicholas Argyres, Kaye Husbands, Georgine Kryda, Richard Lester, Yadong Luo, Aseem Prakash, Metin Sengul, Tieying $\mathrm{Yu}$ and an anonymous reviewer. Information on bargains in the Canadian auto industry was gathered from primary and secondary sources, and through numerous private interviews with industry stakeholders by one of the authors.

\section{References}

Alt, J.E., Carleson, F., Heum, P., Johansen, K., 1999. Asset specificity and the political behavior of firms: lobbying for subsidies in Norway. Int. Organ. 53 (1), 99-116.

Argyres, N., Liebeskind, J.P., 1999. Contractual commitments, bargaining power, and governance inseparability: incorporating history into transaction cost theory. Acad. Manage. Rev. 24, 49-63.

Averyt, W.F., Ramagopal, K., 1999. Strategic disruption and transaction cost economics: the case of the American auto industry and Japanese competition. Int. Bus. Rev. 8, 39-53.

Barney, J., 1991. Firm resources and sustained competitive advantage. J. Manage. 17, 99-120.

Bennett, D.C., Sharpe, K.E., 1979. Agenda setting and bargaining power: the Mexican state versus transnational automobile corporations. World Polit. 32, 57-89.

Boddewyn, J., Brewer, T., 1994. International-business political behavior: new theoretical directions. Acad. Manage. Rev. 19, 119-144.

Brewer, T., 1992. An issue area approach to the analysis of MNE-government relations. J. Int. Bus. Stud. 23, 295-309.

Chen, M.-J., 1996. Competitor analysis and interfirm rivalry: toward a theoretical integration. Acad. Manage. Rev. $21,100-134$.

Crystal, J., 1998. A new kind of competition: how American producers respond to incoming foreign direct investment. Int. Stud. Q. 42, 513-543.

Dunning, J.H., 1993a. Governments and multinational enterprises: from confrontation to cooperation? In: Eden, L., Potter, E. (Eds.), Multinationals in the Global Political Economy. Macmillan, London, pp. 59-83.

Dunning, J.H., 1993b. Multinational Enterprises and the Global Economy. Addison-Wesley, Reading, MA.

Dunning, J.H., 1997. Governments and the macro-organization of economic activity: a historical and spatial perspective. In: Dunning, J.H. (Ed.), Governments, Globalization and International Business. Oxford Univ. Press, Oxford, pp. 31-72.

Eden, L., 1996. The emerging North American investment regime. Transnatl. Corp. 5, 61-98.

Eden, L., Molot, M.A., 1993a. Insiders and outsiders: defining 'who is us?' in the North American auto industry. Transnatl. Corp. 2, 31-64.

Eden, L., Molot, M.A., 1993b. The NAFTA's Automotive Provisions: the Next Stage of Managed Trade. C.D. Howe Institute, Toronto.

Eden, L., Molot, M.A., 1996. Made in America? The US auto industry, 1955-95. Int. Exec. 38, 501-541.

Goodman, J.B., Spar, D., Yoffie, D.B., 1996. Foreign direct investment and the demand for protection in the United States. Int. Organ. 50, 565-591.

Grosse, R., 1996. The bargaining relationship between foreign MNEs and host governments in Latin America. Int. Trade J. 10, 467-499. 
Grosse, R., Behrman, J.N., 1992. Theory in international business. Transnatl. Corp. 1, 93-126.

Hanson, B.T., 1998. What happened to Fortress Europe? External trade policy liberalization in the European Union. Int. Organ. 52, 55-85.

Hathaway, O.A., 1998. Positive feedback: the impact of trade liberalization on industry demands for protection. Int. Organ. 52 (3), 575-612.

Heilein, R., 1961. Stranger in a Strange Land. Putnam Publishing Group, New York.

Hymer, S., 1960/1976. The International Operations of National Firms: a Study of Direct Foreign Investment. MIT Press, Cambridge, MA.

Industry Canada, 1998. The Automotive Competitiveness Review. Government of Canada, Ottawa.

Jenkins, B., 1986. Re-examining the 'obsolescing bargain': a study of Canada's National Energy Program. Int. Organ. 40, 139-165.

Johnson, J.R., 1993. The effect of the Canada-US Free Trade Agreement on the Auto Pact. In: Molot, M.A. (Ed.), Driving Continentally: National Policies and the North American Auto Industry. Carleton Univ. Press, Ottawa, pp. 255-283.

Keillor, B.D., Boller, G.W., Ferrell, O.C., 1997. Firm-level political behavior in the global market place. J. Bus. Res. 40, 113-126.

Kobrin, S., 1987. Testing the bargaining hypothesis in the manufacturing sector in developing countries. Int. Organ. 41, 609-638.

Kostova, T., Zaheer, S., 1999. Organizational legitimacy under conditions of complexity: the case of the multinational enterprise. Acad. Manage. Rev. 24, 64-81.

Lieberman, M.B., Montgomery, D.B., 1998. First-mover (dis)advantages: retrospective and link with the resourcebased view. Strateg. Manage. J. 19, 1111-1125.

Luo, Y., 2001. Toward a cooperative view of MNC-host government relations: building blocks and performance implications. J. Int. Bus. Stud. 32, 401-419.

Mayer, F.W., 1998. Reinterpreting NAFTA: the Science and Art of Political Analysis. Columbia Univ. Press, New York.

Miller, D., Shamsie, J., 1996. The resource-based view of the firm in two environments: the Hollywood film studios from 1936 to 1965 . Acad. Manage. J. 39, 519-543.

Milner, H.V., Yoffie, D.B., 1989. Between free trade and protectionism: strategic trade policy and a theory of corporate trade demands. Int. Organ. 43 (2), 239-272.

Molot, M.A., forthcoming. Automotive Tariffs and Border Bargains: the Experience of the Canadian Auto Industry in a North American Market. Center for Strategic and International Studies, Washington, DC.

Moran, T., 1973. Transnational strategies of protection and defense by multinational corporations: spreading the risk and raising the cost for nationalization in natural resources. Int. Organ. 27, 273-287.

Moran, T. (Ed.), 1985. Multinational Corporations: the Political Economy of Foreign Direct Investment. Lexington Books, Lexington, MA.

Oliver, C., 1997. Sustainable competitive advantage: combining institutional and resource-based views. Strateg. Manage. J. 18, 697-713.

Pauly, L.W., Reich, S., 1997. National structures and multinational corporate behavior: enduring differences in the age of globalization. Int. Organ. 51 (1), 1-30.

Peteraf, M.A., 1993. The cornerstones of competitive advantage: a resource-based view. Strateg. Manage. J. 14, $179-191$.

Ramamurti, R., 2001. The obsolescing 'bargain model'? MNC-host developing country relations revisited. J. Int. Bus. Stud. 32.1, 23-39.

Rugman, A.M., Verbeke, A., 1990. Global Corporate Strategy and Trade Policy. Routledge, London.

Rugman, A.M., Verbeke, A., 1998. Multinational enterprises and public policy. J. Int. Bus. Stud. 29, 115-136.

Shaffer, B., 1995. Firm-level responses to government regulation: theoretical and research approaches. J. Manage. 21, 495-515.

Stopford, J.M., 1994. The growing interdependence between transnational corporations and governments. Transnatl. Corp. 3, 53-76. 
Teece, D.J., Pisano, G., Shuen, A., 1997. Dynamic capabilities and strategic management. Strateg. Manage. J. 18, 509-533.

Thomas, K., 1997. Capital Beyond Borders: States and Firms in the Auto Industry, 1960-94. St. Martins Press, New York.

Vachani, S., 1995. Enhancing the obsolescing bargain theory: a longitudinal study of foreign ownership of US and European multinationals. J. Int. Bus. Stud. 26, 159-180.

Vernon, R., 1971. Sovereignty at Bay: the Multinational Spread of US Enterprises. Basic Books, New York.

Vernon, R., 1977. Storm over the Multinationals: the Real Issues. Harvard Univ. Press, Cambridge, MA.

Yu, T., Eden, L., 2001. Safe in my backyard: strategic trade policy and rivalry among multinational enterprises. Best Paper Proceedings of the Academy of Management.

Zaheer, S., 1995. Overcoming the liability of foreignness. Acad. Manage. J. 38, 341-363.

Zaheer, S., Mosakowski, E., 1997. The dynamics of the liability of foreignness: a global study of survival in financial services. Strateg. Manage. J. 18, 439-464. 